\title{
Phosphorylation of DARPP-32 at Threonine-34 is Required for Cocaine Action
}

\author{
Venetia Zachariou 1,3,6, Véronique Sgambato-Faure ${ }^{2,6,7}$, Teresa Sasaki', Per Svenningsson ${ }^{2}$, Olivier Berton', \\ Allen A Fienberg ${ }^{2,4}$, Angus C Nairn ${ }^{2,5}$, Paul Greengard ${ }^{2}$ and Eric J Nestler ${ }^{*, 1}$ \\ 'Department of Psychiatry and Center for Basic Neuroscience, The University of Texas Southwestern Medical Center, Dallas, TX, USA; \\ ${ }^{2}$ Laboratory of Molecular and Cellular Neuroscience, The Rockefeller University, New York, NY, USA; ${ }^{3}$ Department of Basic Sciences, University of \\ Crete, Heraklion, Crete, Greece; ${ }^{4}$ Intra-Cellular Therapies, Inc., New York, NY, USA; ${ }^{5}$ Department of Psychiatry, Yale University School of Medicine, \\ New Haven, CT, USA
}

\begin{abstract}
Mice lacking DARPP-32, a striatal-enriched phosphoprotein, show abnormal behavioral and biochemical responses to cocaine, but the role of individual phosphorylation sites in DARPP-32 in these responses is unknown. We show here that mutation of Thr-34 in DARPP32 mimicked the behavioral phenotype of the constitutive DARPP-32 knockout in cocaine-induced place conditioning, locomotor activity, and sensitization paradigms. In contrast, mutations of Thr75 did not affect conditioned place preference or the acute locomotor response to cocaine, but DARPP-32 Thr-75 mutants showed no locomotor sensitization in response to repeated cocaine administration. Consistent with these behavioral findings, we found that cocaine regulation of gene expression in striatum, including the acute induction of the immediate early genes c-fos and arc (activity-regulated cytoskeletal-associated gene), was abolished in DARPP-32 Thr-34 mutants, but not in Thr-75 mutants. Similarly, induction of the transcription factor $\Delta$ FosB in the ventral striatum (nucleus accumbens) by chronic cocaine was diminished by the Thr-34, but not the Thr-75, mutation. These findings highlight distinct roles of the Thr-34 and Thr-75 phosphorylation sites of DARPP-32 in mediating short- and long-term behavioral and biochemical actions of cocaine. Neuropsychopharmacology (2006) 31, 555-562. doi: I 0. I038/sj.npp. I 300832; published online 3 August 2005
\end{abstract}

Keywords: place preference; striatum; nucleus accumbens; $\Delta$ FosB; arc; c-fos

\section{INTRODUCTION}

Striatal function is highly regulated by DARPP-32, a $32 \mathrm{kDa}$ phosphoprotein enriched in medium spiny neurons in dorsal and ventral striatum (Greengard, 2001). This protein has a complex mechanism of action, with both protein phosphatase and protein kinase regulatory properties. Upon protein kinase A (PKA) phosphorylation at Thr-34, DARPP32 becomes a potent inhibitor of protein phosphatase 1 (PP1) (Hemmings et al, 1984). On the other hand, phosphorylation of DARPP-32 at Thr-75 by cyclin-dependent kinase- 5 converts it into an inhibitor of PKA (Bibb et al, 1999). Through such actions, DARPP-32 appears to integrate the physiological effects of multiple extracellular and intracellular signals in striatum.

\footnotetext{
*Correspondence: Professor EJ Nestler, Department of Psychiatry, The University of Texas Southwestern Medical Center, 5323 Harry Hines Blvd, Dallas, TX 75390-9070, USA, Tel: + I 214648 IIII, Fax: + I 214648 4947, E-mail: eric.nestler@utsouthwestern.edu ${ }^{6}$ These authors contributed equally to this study.

${ }^{7}$ Current address: INSERM U704, Dynamique des réseaux neuronaux, Joseph Fourier University of Grenoble, 2280 rue de la Piscine, BP53, Grenoble, 3804I, France.

Received I0 February 2005; revised I June 2005; accepted 3 June 2005 Online publication: 20 June 2005 at http://www.acnp.org/citations/ Npp06200505009|/default.pdf
}

DARPP-32 plays a critical role in regulating dopamine signaling in striatum (Greengard, 2001), and dopamine signaling is critical in mediating the actions of psychostimulants such as cocaine and amphetamine (Nestler, 2001). Recent evidence indicates that mice lacking DARPP-32 show abnormal responses to psychostimulants. Loss of DARPP-32 in mice reduces an animal's sensitivity to the acute locomotor activating and rewarding effects of cocaine, and also blunts cocaine's ability to induce the transcription factor c-Fos acutely and the related transcription factor $\triangle \mathrm{FosB}$ (including all of its isoforms) chronically (Fienberg et al, 1998; Hiroi et al, 1999; Zachariou et al, 2002). In contrast, locomotor sensitization to repeated cocaine exposure is paradoxically enhanced in the DARPP-32 knockout mice (Hiroi et al, 1999).

However, the contribution of the regulation of PP1 or PKA by DARPP-32 in mediating these effects of cocaine is unknown. In the present study, using recently generated DARPP-32 mutant mice (Svenningsson et al, 2003), in which either Thr-34 or Thr-75 was mutated to a nonphosphorylatable residue, alanine, we address this important question. We characterize the influence of each mutation on behavioral responses to cocaine. We also investigate the importance of each phosphorylation site in cocaine's ability to regulate gene expression in striatum, including the induction of the transcription factors c-Fos and $\Delta$ FosB. In 
addition, given the likely importance of changes in the neuronal cytoskeleton in molecular adaptations to psychomotor stimulants (Nestler and Aghajanian, 1997; Noble et al, 2000; Robinson and Berridge 2001; Robinson and Kolb, 2004), we investigated the expression of Arc, a cytoskeletal-related protein. Of interest, Arc is induced in striatum by acute cocaine (Fosnaugh et al, 1995; Tan et al, 2000) or chronic morphine (Marie-Claire et al, 2004) and is critically involved in the regulation of synaptic plasticity (for a review, see Steward and Worley, 2002). The results obtained highlight distinct roles of the Thr-34 and Thr-75 sites of DARPP-32 in mediating short- and long-term behavioral and biochemical actions of psychostimulants.

\section{MATERIALS AND METHODS}

\section{Animals}

Homozygous mutant and wild-type mice were generated from heterozygous matings for each mouse line. All of the mutants were generated on a 129SV background; the phosphomutant lines were backcrossed for two generations to a C57Bl/6 background, while the DARPP-32 knockout line was fully backcrossed to this background. Separate groups of male mice were used for each behavioral and biochemical assay.

\section{Conditioned Place Preference}

The place preference apparatus used in this study has been described before (Rahman et al, 2003). Briefly, the apparatus consists of two large chambers with distinct wall patterns and floor textures separated by a smaller chamber. On day 1, baseline preference was monitored for $20 \mathrm{~min}$. For the next 3 days, mice were conditioned to one chamber with saline in the morning and to the opposite chamber with cocaine in the afternoon. On the test day (day 5), conditioned preference was monitored for $20 \mathrm{~min}$. No preference for one of the sides was observed for any of the lines used at baseline. Owing to the different genetic backgrounds of the various mouse lines, threshold cocaine doses were first determined in each behavioral paradigm in wild-type animals for each line.

\section{Locomotor Activity Assays}

Acute locomotor activity assays were performed in an automated system as previously described (Rahman et al, 2003). During habituation, mice were injected i.p. with saline and placed in the locomotor activity cages for $30 \mathrm{~min}$ for 2 consecutive days. Baseline locomotor activity was monitored on day 3 for $30 \mathrm{~min}$ after a saline injection, followed by another $30 \mathrm{~min}$ session of cocaine administration $(20 \mathrm{mg} / \mathrm{kg}$ i.p.). For locomotor sensitization assays, locomotor activity was monitored for $30 \mathrm{~min}$ after an i.p. saline injection (days 1-3), then after daily cocaine injections (20 mg/kg i.p.; days $4-8)$.

\section{Tissue Preparation for In Situ Hybridization}

Mice were killed $1 \mathrm{~h}$ after injection of saline or cocaine and their brains were fixed by intracardiac perfusion of $4 \%$ paraformaldehyde in $0.1 \mathrm{M}$ phosphate buffer, $\mathrm{pH}$ 7.5. Brains were removed and postfixed in the same fixative solution for $2 \mathrm{~h}$, washed overnight in $0.1 \mathrm{M}$ phosphate buffer containing $15 \%$ sucrose, and then frozen. Rostro-caudal series of coronal sections $(20 \mu \mathrm{m})$ were cut on a microtome and then kept in a solution containing $30 \%$ ethylene glycol, $30 \%$ glycerol, $0.1 \mathrm{M}$ phosphate buffer, and $0.1 \%$ diethyl pyrocarbonate (DEPC) at $20^{\circ} \mathrm{C}$ until they were processed for in situ hybridization.

\section{In Situ Hybridization}

${ }^{35} \mathrm{~S}$-radiolabeled antisense riboprobes were used in this study. The Arc probe containing the entire 3232 bases for arc cDNA was subcloned into pBluescriptKS, linearized after EcoRI digestion and transcribed with T7 RNA polymerase. The DARPP- 32 antisense probe $(500 \mathrm{bp}$ fragment of the coding sequence of rat DARPP-32 cDNA subcloned into pBluescriptKS) was linearized after $\mathrm{XbaI}$ digestion and transcribed with T3 RNA polymerase. The $\mathrm{c}$-fos antisense probe was generated from a $2100 \mathrm{bp}$ cDNA fragment encoding the full-length c-fos gene (Curran $e t$ al, 1987), subcloned into pBluescriptKS, linearized with SacII and transcribed with T7 RNA polymerase followed by alkaline phosphatase digestion to generate $300 \mathrm{bp}$ fragments. The transcription reaction contained $6 \mu 1\left[{ }^{35} \mathrm{~S}\right] \mathrm{UTP}$ $(25 \mathrm{mCi} / \mathrm{ml}$; NEN Life Sciences), $250 \mu \mathrm{M}$ ATP, CTP, and GTP, and unlabeled UTP $(10.5 \mu \mathrm{M})$; the reaction mixture was incubated at $37^{\circ} \mathrm{C}$ for $2 \mathrm{~h}$ After DNase I digestion for $15 \mathrm{~min}$, the labeled RNA was purified on microspin G25 columns (Amersham Pharmacia Biotech). Free-floating sections (4-6 per animal) were mounted on SuperFrost slides in RNase-free conditions. Once the sections were dried, in situ hybridization was performed at $55^{\circ} \mathrm{C}$ in humid chambers for $16 \mathrm{~h}$ according to a previous protocol (Sgambato et al, 1998). After coverslips were removed in $4 \times$ SSC and $10 \mathrm{mM} \mathrm{DTT}$, the slides were washed in the same solution for $1 \mathrm{~h}$ at room temperature and then in $50 \%$ formamide, $10 \mathrm{mM}$ Tris- $\mathrm{HCl}, \mathrm{pH} 8,75 \mathrm{mM} \mathrm{NaCl}$, and $2.5 \mathrm{mM}$ EDTA. Sections were treated with RNase A $(20 \mu \mathrm{g} / \mathrm{ml}$; Sigma) in $400 \mathrm{mM} \mathrm{NaCl}, 10 \mathrm{mM}$ Tris-HCl, $\mathrm{pH}$ 7.5, and $50 \mathrm{mM}$ EDTA for $1 \mathrm{~h}$ at $37^{\circ} \mathrm{C}$ and then were rinsed for $15 \mathrm{~min}$ at $60^{\circ} \mathrm{C}$ in $2 \times \mathrm{SSC}$, followed by $0.1 \times$ SSC. After dehydration, the sections were air-dried and exposed to Biomax-MR films (Kodak). Densitometric measurements of mRNA signals were obtained from autoradiograms using the NIH Image J 1.29 software after subtraction of background value. The region used for quantitation was the dorsal striatum at rostral levels (ie anterior relative to Bregma comprised between 0.8 and $0.4 \mathrm{~mm}$ according to the atlas of Franklin and Paxinos (1997). Data are expressed as means \pm SEM. Statistical analysis used ANOVA with multiple comparisons (Newman-Keuls multiple comparison test).

\section{$\Delta$ FosB Immunohistochemistry}

At $18-24 \mathrm{~h}$ after their last treatment, animals were deeply anesthetized with chloral hydrate and perfused intracardiacally with $200 \mathrm{ml}$ of $0.01 \mathrm{M}$ phosphate-buffered saline (PBS) $\mathrm{pH} \mathrm{7.4,} \mathrm{followed} \mathrm{by} 400 \mathrm{ml}$ of $4 \%$ paraformaldehyde in $0.01 \mathrm{M}$ PBS. Brains were removed and stored for $12 \mathrm{~h}$ in $4 \%$ 
paraformaldehyde at $4{ }^{\circ} \mathrm{C}$. The next morning, brains were transferred to a $20 \%$ glycerol in $0.01 \mathrm{M}$ PBS solution for cryoprotection. Coronal sections $(30 \mu \mathrm{m})$ were cut on a freezing microtome (Leica, Bannockburn, IL) and then processed for immunohistochemistry. FosB $/ \Delta$ FosB immunoreactivity was detected using a rabbit polyclonal antibody raised against an N-terminal region of FosB $/ \triangle$ FosB (SC7203, Santa Cruz Biotechnology, Santa Cruz, CA). FosB staining was revealed by use of a fluorescent secondary antibody. Slices were incubated for $30 \mathrm{~min}$ in $0.1 \%$ Triton X100 and $3 \%$ normal donkey serum to minimize nonspecific labeling. Tissue sections were then incubated overnight at room temperature in $1 \%$ normal donkey serum, $0.1 \%$ Triton X-100, and anti-FosB antibody (SC-7203; 1:500). Sections were washed, placed for $1.5 \mathrm{~h}$ in a $1: 200$ dilution of CY2-labeled donkey anti-rabbit IgG (Jackson immunoresearch). The total number of cells immunoreactive for FosB/ $\Delta$ FosB was counted in the NAc (core and shell) by an
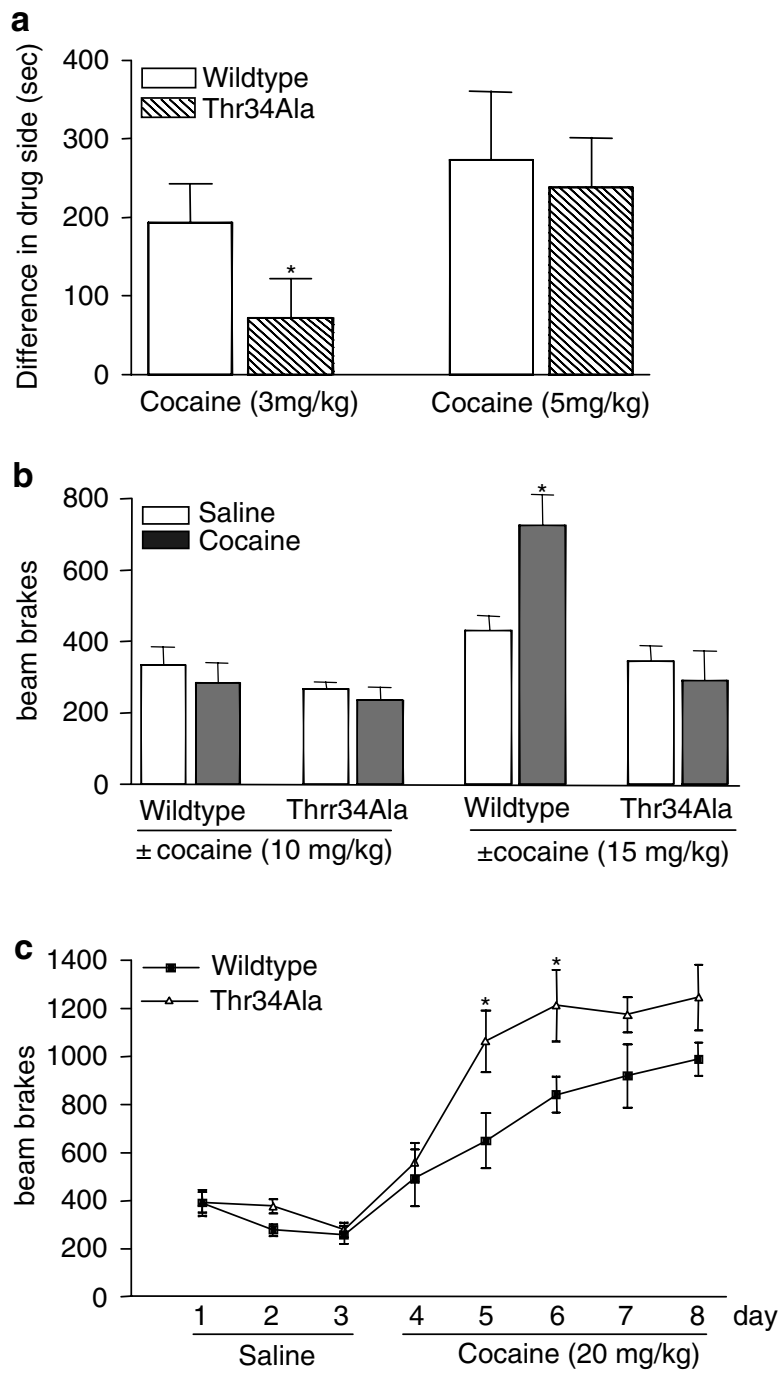

experimenter blind to the experimental conditions. The analysis was performed using a Leeds microscope equipped with an $\mathrm{x}-\mathrm{y}-\mathrm{z}$ stage connected to a personal computer running Bioquant Nova (Bioquant Image Analysis, Nashville, TN).

\section{RESULTS}

\section{Behavioral Responses to Cocaine in DARPP-32 Mutant Mice}

DARPP-32 Thr-34 mutants were first analyzed for their behavioral responses to cocaine. As shown in Figure 1a, mutation of Thr-34 to Ala decreases sensitivity to cocaine's rewarding effects in the place preference paradigm, as mutant mice required higher doses of cocaine to show significant place conditioning compared to their wild-type littermates. The Thr-34 mutant mice also showed reduced
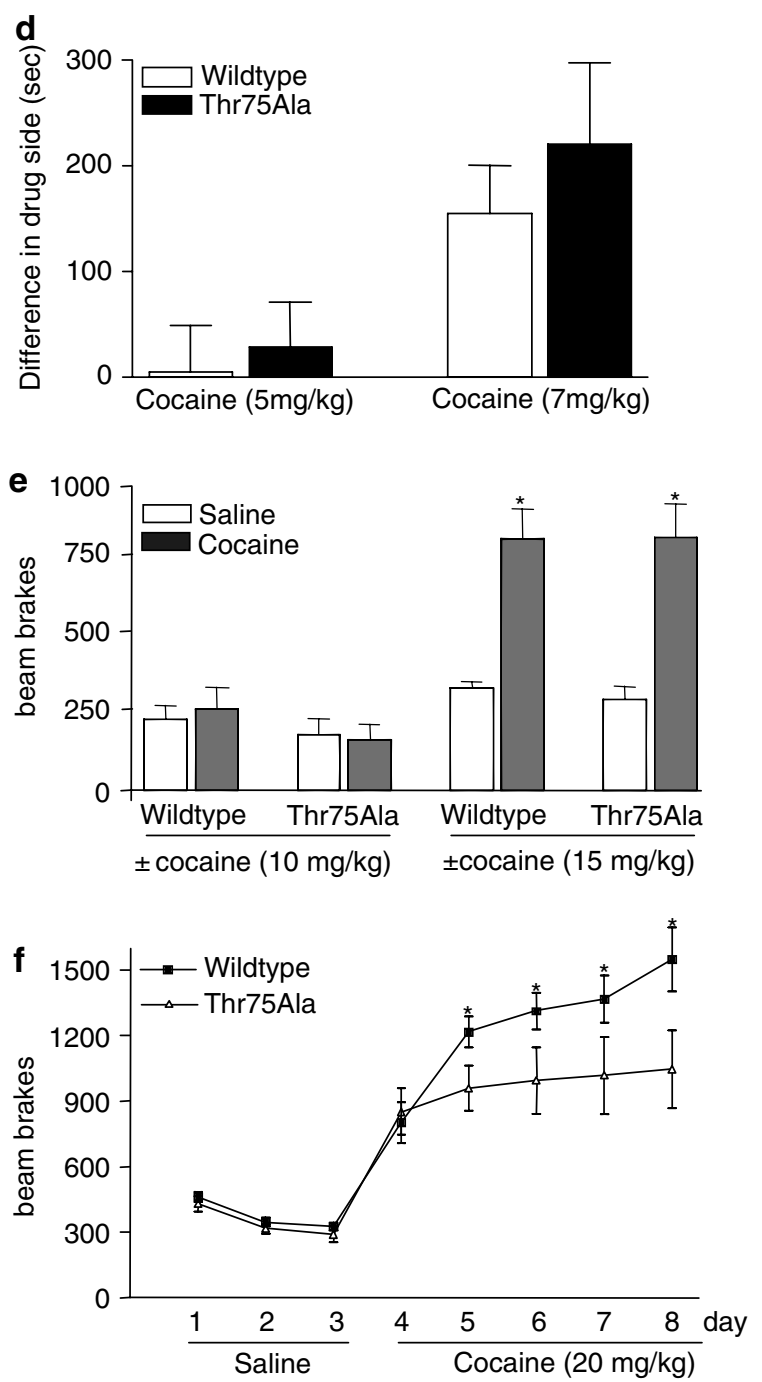

Figure I Behavioral responses to cocaine in Thr-34 and Thr-75 DARPP-32 mutant mice. Thr-34 mutants showed (a) reduced sensitivity to cocaine place conditioning as they develop place preference to higher doses than their wild-type littermates $(n=4-7)$, (b) reduced acute locomotor responses to cocaine $(n=4)$, but (c) enhanced locomotor sensitization to repeated cocaine $(n=7-9)$. In contrast, Thr-75 mutants showed (d) normal cocaine place conditioning $(n=6-7)$ and (e) acute locomotor responses to cocaine $(n=4)$, but ( $f$ ) reduced locomotor sensitization (response on day 8 vs day 4$)$ to repeated cocaine $(n=7$ per group). Data are expressed as mean \pm SEM, * $p<0.05$ between genotypes over dose (for place conditioning and locomotor activity) or between genotypes over treatment day (for locomotor sensitization) by ANOVA followed by PLSD test. Note that dose responses to cocaine differed in the wildtype mice for the Thr-34 and Thr-75 mutants due to the somewhat different backgrounds of the lines. 
sensitivity to the acute locomotor effects of cocaine. Cocaine at $10 \mathrm{mg} / \mathrm{kg}$ had no effect on locomotor activity in either wild-type or Thr-34 mutant mice, while cocaine at $15 \mathrm{mg} / \mathrm{kg}$ increased locomotor activity in wild-type mice, but not in Thr-34 mutant mice (Figure 1b). At the dose of $20 \mathrm{mg} / \mathrm{kg}$, cocaine increased locomotor activity to the same level in both wild-type and Thr-34 mutant mice (data not shown). However, this high dose of cocaine $(20 \mathrm{mg} / \mathrm{kg})$ caused an abnormal pattern of sensitization to repeated cocaine administration in the Thr-34 mutants, with a maximal increase in locomotor activity reached upon the second exposure to the drug (Figure 1c).

Very different results were obtained in the DARPP-32 Thr-75 mutants. Loss of Thr-75 had no influence on the animal's sensitivity to the rewarding effects of cocaine as measured in the place preference paradigm (Figure 1d), nor was there any difference in locomotor responses induced by acute injection of the drug (Figure 1e). However, the DARPP-32 Thr-75 mutants showed no locomotor sensitization in response to repeated cocaine administration (Figure 1f), a phenotype opposite to that seen in the Thr34 mutants. These behavioral findings are consistent with the opposing effects of DARPP-32 Thr-34 and Thr-75 phosphorylation on PKA signaling in striatum (Bibb et al, 1999; Greengard 2001).

\section{Induction of Fos Family Transcription Factors in DARPP-32 Mutant Mice}

Acute exposure to cocaine causes the rapid and transient induction of c-Fos in the nucleus accumbens and dorsal striatum, while repeated cocaine administration selectively induces $\Delta$ FosB in these regions (Nestler et al, 2001). The latter protein has been related to some of the longer-lasting effects of cocaine (Nestler et al, 2001; McClung et al, 2004). Interestingly, the ability of an acute cocaine injection $(10 \mathrm{mg} / \mathrm{kg}$ ) to induce c-fos (Figure 2) or fosb (data not shown) mRNA in the nucleus accumbens was significantly attenuated in the Thr-34 mutant mice, while such induction was normal in the Thr-75 mutant mice (Figure $2 \mathrm{a}$ and $\mathrm{b}$ ). At a higher dose $(20 \mathrm{mg} / \mathrm{kg})$, cocaine induced $c$-fos expression in the Thr-34 mutants to levels only slightly lower than their wild-type controls. Importantly, induction of $\Delta \mathrm{FosB}$ in the nucleus accumbens by chronic cocaine administration was reduced dramatically in the Thr-34 mutant mice (Figure $2 \mathrm{c}$ and d), but was not significantly affected in Thr-75 mutant mice (number of $\Delta$ FosB-positive cells: wild-type saline $=$ $29.6 \pm 11.6$, wild-type cocaine $=150 \pm 21.8$, mutant saline $=$ $25 \pm 12$, mutant cocaine $=124 \pm 20.8, n=4-5$ ).

\section{Induction of Arc in DARPP-32 Mutant Mice}

We next investigated the effect of cocaine on arc gene expression. Arc mRNA is expressed at relatively low levels constitutively (Figure 3a). Using treatment parameters $(20 \mathrm{mg} / \mathrm{kg}, 1 \mathrm{~h})$ that elicit robust activation of other immediate early genes like $c$-fos, we found that cocaine also induced arc mRNA in wild-type mice (Figure $3 \mathrm{a}$ and $\mathrm{b}$ ) throughout most of the dorsal striatum at rostral levels, and in a large centromedial region at caudal levels. In the nucleus accumbens, arc induction was much lower in magnitude than in the dorsal striatum. These results are in a
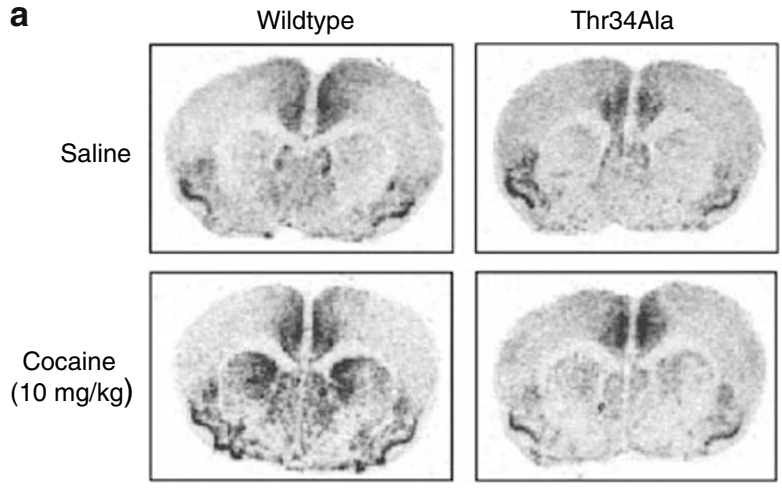

b
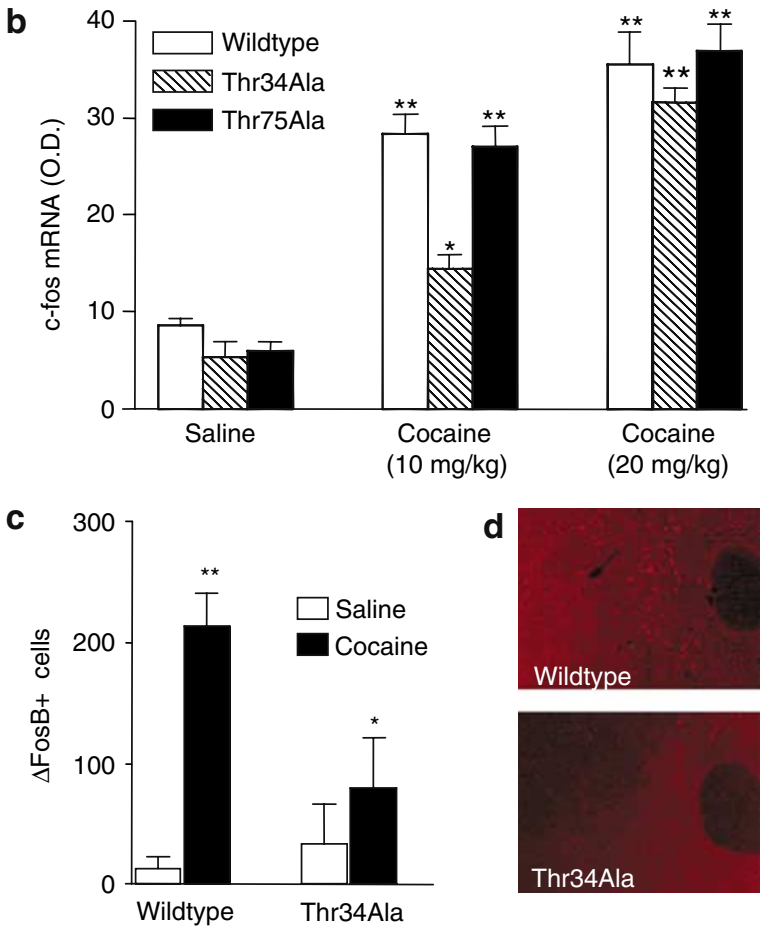

Figure 2 Induction of c-fos and $\Delta$ FosB in Thr-34 and Thr-75 DARPP-32 mutant mice. Thr-34 mutants showed attenuated induction of c-fos mRNA after acute cocaine injection (a, b; $20 \mathrm{mg} / \mathrm{kg}$ i.p., $n=5$ per group), whereas Thr-75 mice showed normal c-fos responses (b). Data for nucleus accumbens are expressed as mean + SEM, $* p<0.05$ between genotypes, *** $<0.05$ between cocaine and saline, by ANOVA followed by PLSD. Thr-34 mutants also show attenuated $\triangle$ FosB induction after repeated cocaine administration (c, d; $20 \mathrm{mg} / \mathrm{kg}$ i.p. daily for 7 days, $n=5-6$ per group). Data for nucleus accumbens are expressed as mean $\pm \mathrm{SEM}$, ${ }^{*} p<0.05$ between genotypes, $* * * 0.05$ between cocaine and saline ANOVA followed by PLSD test.

agreement with previous data obtained in the rat (Tan et al, 2000). Characterization of this response revealed that mRNA levels were elevated within $15 \mathrm{~min}$ of cocaine administration (data not shown). In assessing the effect of various doses of cocaine, we found that smaller responses were elicited following injections of $10 \mathrm{mg} / \mathrm{kg}$, with no effect detected at a lower dose $(5 \mathrm{mg} / \mathrm{kg}$ ) (Figure 3a). The response elicited by $20 \mathrm{mg} / \mathrm{kg}$ appeared to be near maximal, as increasing the dose to $40 \mathrm{mg} / \mathrm{kg}$ elicited a similar response (data not shown). These results are in agreement with previous data obtained in the rat (Fosnaugh et al, 1995). 
a
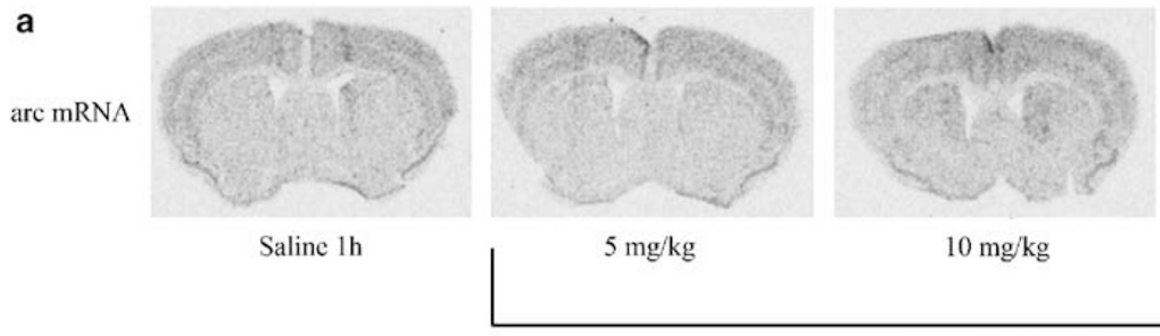

$10 \mathrm{mg} / \mathrm{kg}$

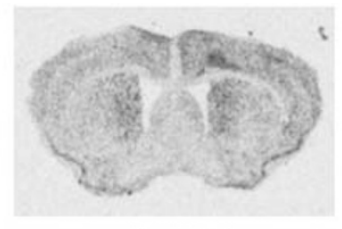

Saline $1 \mathrm{~h}$

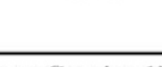

b

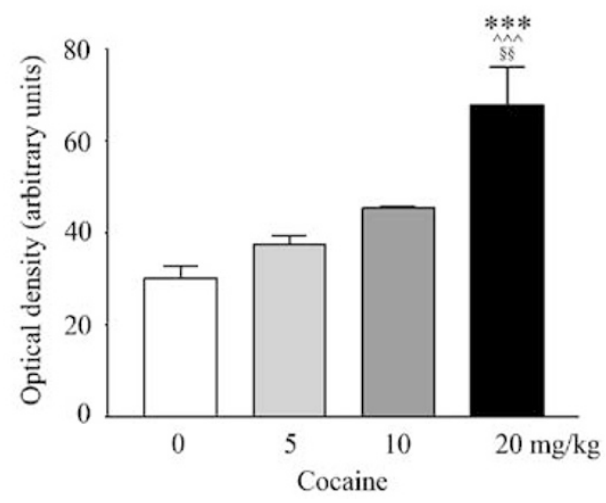

Figure 3 Cocaine-driven induction of arc mRNA in the striatum of wild-type mice is dose dependent. (a) Mice were killed I h after a single i.p. injection with saline or cocaine at 5, 10, or $20 \mathrm{mg} / \mathrm{kg}$. Brain sections (5-6 sections per mouse, $n=4-5$ per group) were then processed in parallel for in situ hybridization of arc mRNA. (b) Data for dorsal striatum are expressed as mean \pm SEM. Statistical significance was assessed by ANOVA with multiple comparisons (Newman-Keuls multiple comparison test): ${ }^{* * * *} p<0.00$ I when compared to injection with saline; ${ }^{\wedge} \wedge \wedge p<0.0$ I when compared to injection with cocaine at $5 \mathrm{mg} / \mathrm{kg} ;{ }^{\$ \S} \mathrm{p}<0.01$ when compared to injection with cocaine at $10 \mathrm{mg} / \mathrm{kg}$.

Cocaine-driven arc induction was next analyzed in DARPP-32 knockout mice (Figure 4a) Adjacent brain sections of saline- or cocaine-treated wild-type or knockout mice were processed in parallel for in situ hybridization of DARPP-32 (Figure 4a, upper panels) and arc (lower panels) mRNAs. As expected, arc mRNA was significantly induced by acute cocaine bilaterally in the dorsal striatum of wildtype mice (Figure 4a), but this induction was completely lost in the DARPP-32 knockout mice (Figure 4a). These data strongly suggest that Arc is a target of DARPP-32-mediated signaling in striatal neurons. Using DARPP-32 Thr-34 (Figure $4 \mathrm{~b}$ ) and Thr-75 (Figure 4c) mutants, we investigated the role of each phosphorylation site in the regulation of arc mRNA induction. As shown in Figure $4 \mathrm{~b}$, the induction of arc mRNA by cocaine was significantly reduced in the dorsal striatum of Thr-34-mutant mice, but normal in Thr-75 mutant mice (Figure 4c).

\section{DISCUSSION}

We examined the role of Thr-34 and Thr-75 DARPP-32 phosphorylation sites in behavioral and biochemical responses to cocaine. The results obtained reveal distinct roles for these two sites in DARPP-32 in mediating shortand long-term actions of this psychostimulant drug. The findings from studies using the Thr-34 mutant mice highlight the importance of the role of DARPP-32 and its inhibition of PP1 in mediating acute actions of cocaine. The results obtained also reveal unexpected roles for the Thr-34 and Thr-75 sites in mediating certain sustained actions of cocaine.

DARPP-32 Thr-34 mutant mice show reduced sensitivity to the rewarding and acute locomotor activating effects of cocaine. Moreover, cocaine-dependent regulation of gene expression in the striatum of the Thr-34 mutant mice generally parallels the behavioral consequences of this mutation. The induction of $c$-fos mRNA in striatum caused by acute cocaine is lost in the Thr-34 mutant mice. Similarly, the induction of $\triangle \mathrm{FosB}$ in the nucleus accumbens caused by chronic cocaine is lost in the Thr-34 mutant mice. Notably, loss of Thr-34 in DARPP-32 results in a behavioral and biochemical phenotype with respect to acute and chronic cocaine administration that is the same as that observed in DARPP-32 knockout mice (Fienberg et al, 1998; Hiroi et al, 1999; Snyder et al, 2000). Sustained induction of $\Delta F o s B$ in the nucleus accumbens following repeated exposure to cocaine or other drugs of abuse leads to numerous neuronal adaptations via regulation of the expression of a wide range of gene targets (Nestler et al, 2001; McClung and Nestler, 2003). The loss of $\Delta$ FosB induction could account for the reduction in rewarding responses to cocaine seen in the DARPP-32 Thr-34 and knockout mice, since direct blockade of $\triangle F o s B$ activity results in a similar phenotype (Peakman et al, 2003).

These findings support an essential role of PKA phosphorylation of DARPP-32 at Thr-34 in cocaine action. DARPP-32 is likely to play a critical role in amplifying the actions of D1-receptor/cAMP signaling to ensure robust activation of downstream signaling targets. Important targets are likely to include ERK and subsequent regulation 

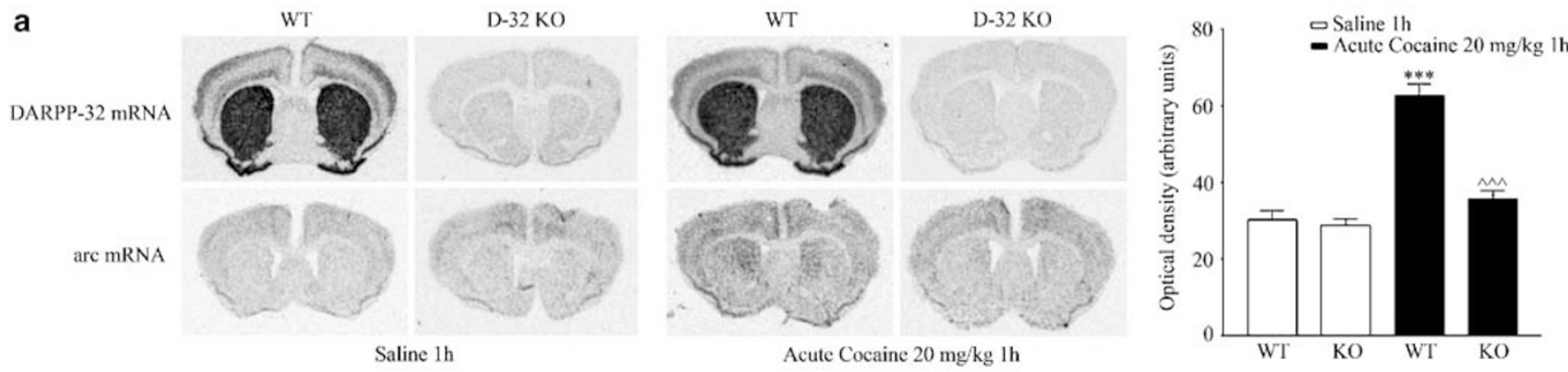

b
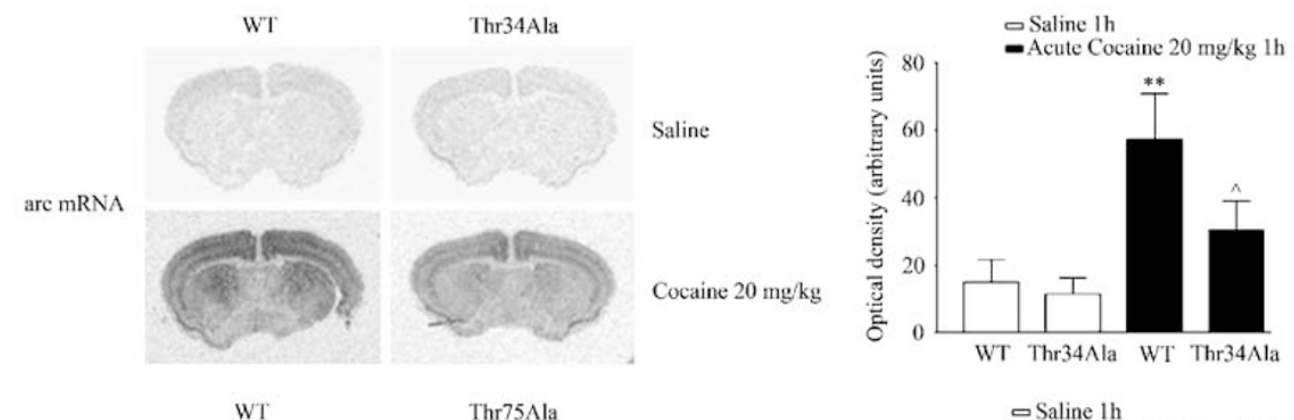

c
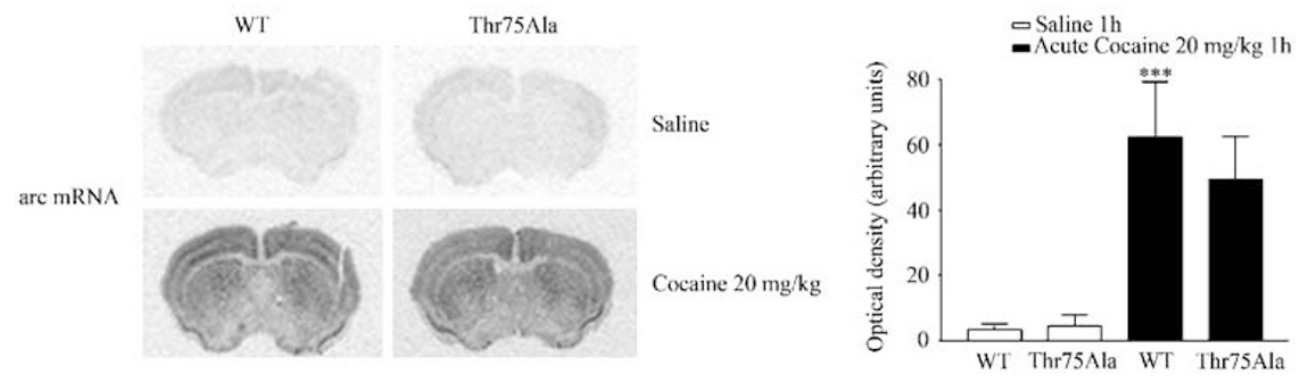

Figure 4 Induction of arc mRNA in DARPP-32 KO mice and in Thr-34 and Thr-75 DARPP-32 mutant mice. (a, upper panels) DARPP-32 mRNA; (a, lower panels; b, c) arc mRNA. DARPP-32 KO (a, $n=5$ per group) and Thr-34 (b, $n=5$ per group) mutant mice showed attenuated induction of arc mRNA after acute cocaine injection ( $20 \mathrm{mg} / \mathrm{kg}$ i.p.), whereas Thr-75 mutants (c, $n=3-4$ per group) show normal levels of induction. Five to six brain sections per mouse were used for these studies. Data for dorsal striatum are expressed as mean \pm SEM. Statistical significance was assessed by ANOVA with multiple comparisons (Newman-Keuls multiple comparison test): $* * * *<0.001$ or $* * p<0.01$ when compared to injection with saline in the wild-type (WT) mice; $\wedge \wedge \wedge p<0.00$ I or $\wedge p<0.05$ when compared to injection with cocaine at $20 \mathrm{mg} / \mathrm{kg}$ in the WT mice.

of CREB-dependent transcription. In support of this, recent studies have found that Thr-34 of DARPP-32 is necessary for the activation of ERK by several drugs of abuse, including cocaine (Valjent et al, 2005). In this respect, phosphorylation of Thr-34 of DARPP-32 and inhibition of PP1 is required for normal acute responses to cocaine, including its acute behavioral effects and its initial regulation of gene expression. DARPP-32 is also apparently required for the slower accumulation of $\Delta \mathrm{FosB}$, which is seen following chronic cocaine administration (Nestler et al, 2001).

Interestingly, the Thr-34 mutant mice show an abnormal pattern of locomotor sensitization to repeated cocaine exposure, with maximal sensitization occurring more rapidly compared to wild-type mice. The same pattern of locomotor sensitization was also observed in DARPP-32 knockout mice (Fienberg et al, 1998; Hiroi et al, 1999). However, the loss of $\triangle$ FosB induction seen in the DARPP-32 Thr-34 and knockout mice cannot explain the accelerated locomotor sensitization seen in these mice, since increased $\Delta$ FosB levels enhance locomotor responses to cocaine and blockade of $\Delta$ FosB has no effect (Kelz et al, 1999; Peakman et al, 2003). The molecular basis for the phenomenon of accelerated locomotor sensitization to cocaine observed in the DARPP-32 Thr-34 and knockout mice is not known at this time. These observations raise the possibility that, in addition to its role in signal amplification being coupled to positive aspects of D1/cAMP signaling, phosphorylation of Thr-34 plays an additional negative feedback role. Alternatively, since the locomotor sensitizing $v s$ rewarding effects of cocaine are likely mediated by complex striatal and nonstriatal networks, DARPP-32 and inhibition of PP1 may have functionally opposing roles in these various networks.

The rewarding and locomotor activating effects of cocaine are not affected by deletion of the Thr-75 phosphorylation site of DARPP-32. Our previous studies showed that acute inhibition of DARPP-32 phosphorylation at Thr-75 achieved by local infusion of a Cdk-5 inhibitor into the nucleus accumbens caused increased locomotor sensitization (Bibb et al, 1999). These and other studies supported the hypothesis that Cdk-5, and phosphorylation of Thr-75 
in DARPP-32, play a negative-feedback role in the actions of cocaine, likely via the ability of Thr-75 DARPP-32 to inhibit PKA and its phosphorylation of DARPP-32 at Thr-34 among other substrates. Removal of the inhibitory Thr-75 site in the mutant mice would be expected to alter the setpoint of PKA- and DARPP-32 Thr-34-dependent signaling, and to lead to an increased sensitivity to cocaine. Notably, in direct contrast to the Thr-34 mutant mice, the Thr-75 mutant mice exhibited no locomotor sensitization to repeated cocaine. This discrepancy could be due to the different effect of acute $v s$ constitutive loss of Thr-75 in the two situations. It also could relate to the fact that the Thr-75 mutation affects DARPP-32 function in all cells in which the protein is expressed, with different consequences for sensitization occurring in regions other than the nucleus accumbens. While further work is needed to study these possibilities, it is likely that the molecular basis for the effect of Thr-75 on locomotor sensitization results from an unknown negative feedback function of DARPP-32, as discussed above for the Thr-34 mice. In any event, the present results further support antagonistic properties of Thr-34 and Thr-75 phosphorylation in the actions of DARPP-32.

Consistent with our findings on c-fos induction, cocainedriven induction of arc mRNA was also abolished in DARPP-32 knockout mice, as well as in DARPP-32 Thr-34 mutants, but not in Thr-75 mutants. Arc is highly enriched in neuronal dendrites where its distribution parallels that of F-actin (Lyford et al, 1995), and where it interacts with cytoskeletal proteins such as MAP-2 (Fujimoto et al, 2004). Arc is unique among immediate early genes, in that its mRNA rapidly localizes to discrete dendritic regions that have received direct synaptic stimulation (Steward et al, 1998; Steward and Worley, 2002). Moreover, Arc protein is required for long-term potentiation as well as certain forms of memory (Guzowski et al, 2000; Plath et al, 2001; Ying et al, 2002), and promotes CaM/kinase II-dependent neurite extension (Donai et al, 2003). Our results add Arc as an important downstream molecular target for DARPP-32, and provide further support for a role for DARPP-32 in the regulation of synaptic plasticity in the basal ganglia.

Together, our findings support an essential role of PKA phosphorylation of DARPP-32 at Thr-34 in cocaine action. Our hypothesis is that PKA phosphorylation of DARPP-32, and its subsequent inhibition of PP1, is required for normal acute responses to dopamine signals. Such responses mediate cocaine's acute behavioral effects and its ability to induce c-fos, fos $b$, and arc initially. These responses are also required for the accumulation of $\Delta$ FosB, which is seen after chronic cocaine (Nestler et al, 2001). In contrast, the absence of DARPP-32's PP1 inhibitory activity leads to differential adaptations to repeated perturbations in dopamine signaling, with the ultimate result of enhanced locomotor sensitization to chronic cocaine. We hypothesize that loss of DARPP-32's PKA inhibitory activity, through mutation of Thr-75, leads to opposing adaptations and to inhibition of locomotor sensitization, even though it does not affect acute dopamine signaling. While further work is needed to understand the molecular basis of such abnormal adaptations, these results highlight the complex and central role of DARPP-32 in mediating behavioral and molecular plasticity to cocaine.

\section{ACKNOWLEDGEMENTS}

This work was supported by grants from the National Institute on Drug Abuse and National Institute of Mental Health to PG, ACN and EJN. We thank Peter Ingrassia and Cathy Steffen for assistance with mouse breeding and genotyping, as well as E Giggs for help with the figures. We also thank Drs PF Worley and RF Paletzki for the generous gift of the arc plasmid.

\section{REFERENCES}

Bibb JA, Snyder GL, Nishi A, Yan Z, Meijer L, Fienberg AA et al (1999). Phosphorylation of DARPP-32 by Cdk5 modulates dopamine signalling in neurons. Nature 402: 669-671.

Curran T, Gordon MB, Rubino KL, Sambucetti LC (1987). Isolation and characterization of the c-fos (rat) cDNA and analysis of postrnslational modifications in vitro. Oncogene 2: 79-84.

Donai H, Sugiura H, Ara D, Yoshimura Y, Yamagata K, Yamauchi $\mathrm{T}$ (2003). Interaction of Arc with CaM kinase II and stimulation of neurite extension by Arc in neuroblastoma cells expressing CaM kinase II. Neurosci Res 47: 399-408.

Fienberg AA, Hiroi N, Mermelstein PG, Song W, Snyder GL, Nishi A et al (1998). DARPP-32: regulator of the efficacy of dopaminergic neurotransmission. Science 281: 838-842.

Fosnaugh JS, Bhat RV, Yamagata K, Worley PF, Baraban JM (1995). Activation of arc, a putative 'effector' immediate early gene, by cocaine in rat brain. J Neurochem 64: 2377-2380.

Franklin KBJ, Paxinos G (1997). The Mouse Brain in Stereotaxic Coordinates. Academic pres: New York.

Fujimoto T, Tanaka H, Kumamaru E, Okamura K, Miki N (2004). Arc interacts with microtubules/microtubule-associated protein 2 and attenuates microtubule-associated protein 2 immunoreactivity in the dendrites. J Neurosci Res 76: 51-63.

Greengard P (2001). The neurobiology of slow synaptic transmission. Science 294: 1024-1030.

Guzowski JF, Lyford GL, Stevenson GD, Houston FP, McGaugh JL, Worley PF et al (2000). Inhibition of activity-dependent arc protein expression in the rat hippocampus impairs the maintenance of long-term potentiation and the consolidation of longterm memory. J Neurosci 20: 3993-4001.

Hemmings Jr HC, Greengard P, Tung HY, Cohen P (1984). DARPP-32, a dopamine-regulated neuronal phosphoprotein, is a potent inhibitor of protein phosphatase-1. Nature 310: 503-505.

Hiroi N, Feinberg A, Haile C, Alburges M, Hanson GR, Greengard $\mathrm{P}$ et al (1999). Neuronal and behavioural abnormalities in striatal function in DARPP-32 mutant mice. Eur J Neurosci 11: 1114-1118.

Kelz MB, Chen JS, Carlezon WA, Whisler K, Gilden L, Beckmann $\mathrm{AM}$ et al (1999). Expression of the transcription factor $\Delta$ FosB in the brain controls sensitivity to cocaine. Nature 401: 272-276.

Lyford GL, Yamagata K, Kaufmann WE, Barnes CA, Sanders LK, Copeland NG et al (1995). Arc, a growth factor and activityregulated gene, encodes a novel cytoskeleton-associated protein that is enriched in neuronal dendrites. Neuron 14: 433-445.

Marie-Claire C, Courtin C, Roques BP, Noble F (2004). Cytoskeletal genes regulation by chronic morphine treatment in rat striatum. Neuropsychopharmacology 29: 2208-2215.

McClung CA, Nestler EJ (2003). Regulation of gene expression and cocaine reward by CREB and $\triangle$ FosB. Nat Neurosci 11: 1208-1215.

McClung CA, Ulery PG, Perrotti LI, Zachariou V, Berton O, Nestler EJ (2004). FosB: a molecular switch for long-term adaptation. Mol Brain Res 132: 146-154.

Nestler EJ (2001). Molecular basis of long term adaptations underlying addiction. Nat Rev Neurosci 2: 119-128. 
Nestler EJ, Aghajanian GK (1997). Molecular and cellular basis of addiction. Science 278: 58-63.

Nestler EJ, Barrot M, Self DW (2001). FosB: a molecular switch for addiction. Proc Natl Acad Sci USA 98: 11042-11046.

Noble F, Szucs M, Kieffer B, Roques BP (2000). Overexpression of dynamin is induced by chronic stimulation of mu but not deltaopioid receptors: relationships with mu related morphine dependence. Mol Pharmacol 58: 159-166.

Peakman MC, Colby C, Perrotti LI, Tekumalla P, Carle T, Ulery P et al (2003). Inducible, brain region specific expression of a dominant negative mutant of c-Jun in transgenic mice decreases sensitivity to cocaine. Brain Res 970: 73-86.

Plath N, Ohana O, Dammermann B, Waltereit R, Husi H, Blanquet $\mathrm{V}$ et al (2001). Aberrant LTP in arg3.1/ARC knockout animals. Soc Neurosci Abstr 27: 1598.

Rahman Z, Schwartz J, Gold SJ, Zachariou V, Wein MN, Choi KH et al (2003). RGS9-2 modulate dopamine signaling in the basal ganglia. Neuron 38: 941-952.

Robinson TE, Berridge KC (2001). Incentive-sensitization and addiction. Addiction 96: 103-114.

Robinson TE, Kolb B (2004). Strucutural plasticity associated with exposure to drugs of abuse. Neuropharmacology 47: 33-46.

Sgambato V, Pagès C, Rogard M, Besson M-J, Caboche J (1998). Extracellular signal-regulated kinase (ERK) controls immediate early gene induction through corticostriatal stimulation. J Neurosci 18: 8814-8825.

Snyder GL, Allen PB, Fienberg AA, Valle CG, Huganir RL, Nairn AC et al (2000). Regulation of phosphorylation of the GluR1 AMPA receptor in the neostriatum by dopamine and psychostimulants in vivo. J Neurosci 20: 4480-4488.
Steward O, Wallace CS, Lyford GL, Worley PF (1998). Synaptic activation causes the mRNA for the IEG Arc to localize selectively near activated postsynaptic sites on dendrites. Neuron 21: 741-751.

Steward O, Worley P (2002). Local synthesis of proteins at synaptic sites on dendrites: role in synaptic plasticity and memory consolidation? Neurobiol Learn Mem 78: 508-527.

Svenningsson P, Tzavara ET, Carruthers R, Rachleff I, Wattler S, Nehls $M$ et al (2003). Diverse psychotomimetics act through a common signaling pathway. Science 302: 1412-1415.

Tan A, Moratalla R, Lyford GL, Worley P, Graybiel AM (2000). The activity-regulated cytoskeletal-associated protein arc is expressed in different striosome-matrix patterns following exposure to amphetamine and cocaine. J Neurochem 74: 2074-2078.

Valjent E, Pascoli V, Svenningsson P, Paul S, Enslen H, Corvol JC et al (2005). Regulation of a protein phosphatase cascade allows convergent dopamine and glutamate signals to activate ERK in the striatum. Proc Natl Acad Sci USA 102: 491-496.

Ying SW, Futter M, Rosenblum K, Webber MJ, Hunt SP, Bliss TV et al (2002). Brain-derived neurotrophic factor induces longterm potentiation in intact adult hippocampus: requirement for ERK activation coupled to CREB and up-regulation of Arc synthesis. J Neurosci 22: 1532-1540.

Zachariou V, Benoit-Marand M, Allen PB, Ingrassia P, Fienberg AA, Gonon $\mathrm{F}$ et al (2002). Reduction of cocaine place preference in mice lacking the protein phosphatase 1 inhibitors DARPP 32 or Inhibitor 1. Biol Psychiatry 51: 612-620. 